\title{
Diacronie
}

Studi di Storia Contemporanea

$N^{\circ} 13,1 \mid 2013$

Contrabbandieri, pirati e frontiere: per una storia delle pratiche informali nell'America Centrale (XVII-XXI

secolo)

\section{A Horde of Foreign Freebooters}

The U.S. and the Suppression of the Slave Trade

\section{Sarah Batterson}

\section{(2) OpenEdition \\ Journals}

\section{Electronic version}

URL: http://journals.openedition.org/diacronie/720

DOI: $10.4000 /$ diacronie. 720

ISSN: 2038-0925

\section{Publisher}

Association culturelle Diacronie

\section{Electronic reference}

Sarah Batterson, «A Horde of Foreign Freebooters », Diacronie [Online], N 13, 1 | 2013, document 7 ,

Online since 01 April 2013, connection on 19 April 2019. URL : http://journals.openedition.org/ diacronie/720 ; DOI : 10.4000/diacronie.720 


\title{
Diacronie
}

\section{A Horde of Foreign Freebooters \\ The U.S. and the Suppression of the Slave Trade}

\author{
Sarah BATTERSON *
}

Between 1808 and 1820, the U.S. Congress enacted increasingly punitive laws against slave trading. This paper argues that these acts were used to protect U.S. commerce and assert national sovereignty against other nations since, during this time period, the lines between pirate and legal merchant often blurred and threatened legitimate trade. It is no coincidence that the Slave Trade Acts were passed to increase the federal protection of commerce, especially after several real threats to U.S. commercial interests. While the territories in question were not on U.S. soil, informal smuggling networks caused the illegal import of commodities and slaves into the United States. I illustrate how the U.S. employed laws against the slave trade to demonstrate its national strength in these border conflicts.

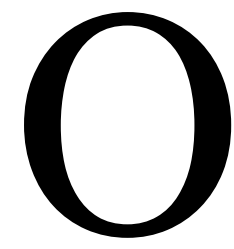

n January 10, 1818, a special Congressional committee submitted a report justifying the United States' recent invasion of Spanish-owned Eastern Florida at a place called Amelia Island. The Spanish minister to the United States, Luis Onís, was furious that the United States seemed to be supporting the revolutionary governments in South America, whose privateers preyed on Spanish shipping. He was also incensed that the United States had the audacity to invade a foreign territory while at peace, even though Eastern Florida had, until the U.S. intervened, been occupied by men claiming to be "liberating" the territory from Spain. The Congressional committee sought to justify their actions by arguing that the «itinerant establishers of republics [in Florida] are [...] prostituted by a horde of foreign 
freebooters, for purposes of plunder» ${ }^{1}$. From the United States' perspective, these pirates, otherwise known as freebooters, were threatening the "security, tranquility, and commerce of this Union," and had to be stopped. Since the Spanish government had shown itself to be incapable of controlling its territories, Congress argued that a U.S. invasion of the unruly territory was completely justified.

In response to Onís's criticism, Congress argued that the federal government had indeed acted appropriately against the pirates and smugglers. In rationalizing their invasion of Spanish Florida in 1817, the U.S. government stated that these pirates had caused the illegal importation of thousands of West Indian and African slaves into U.S. territories through Spanish Florida. This argument in turn allowed the federal government to justify its assertion of national power for the protection of commerce and the control of its borders. The U.S. government would use the border conflict to increase the reach of the federal government.

After the Amelia Island crisis of 1817, the United States Congress passed several new acts increasing federal power, including several slave trade acts. These acts have been lauded by some historians as evidence that the U.S. government did seek to end the slave trade for increasingly moral reasons ${ }^{2}$. I argue, however, that even though abolitionist societies did see increased membership during this time, these acts were primarily aimed at protecting U.S. commercial interests as war in South America and Europe destabilized U.S. border regions. The U.S. Supplementary Slave Trade Acts of 1818-1820 created the strongest anti-slave trade laws in the world. It is no coincidence that they were enacted in conjunction with other laws aimed at increasing the federal protection of U.S. commerce, particularly in the wake of several real threats to U.S. commercial interests, namely at the piratical strongholds of Galveston, in the Gulf of Mexico, and Amelia Island in Eastern Florida. The activities of their inhabitants threatened U.S. shipping and caused the illegal smuggling of thousands of dollars of goods and slaves into the United States. Complications arose on a diplomatic level as these pirates claimed their legitimacy as wartime privateers through South American republics-new nations the United States tacitly supported. All these factors led to tighter U.S. commercial protection laws, which included laws designed to strengthen federal slave trade laws.

\footnotetext{
${ }^{1}$ House Document, $15^{\text {th }}$ Cong., $1^{\text {st }}$ Session, No. 290. "Suppression of Piratical Establishments." January 10, 1818. 133 .

2 See for example, FEHRENBACHER, Don, The Slaveholding Republic, London, Oxford University Press, 2001; FINKELMAN, Paul, «Regulating the African Slave Trade», in Civil War History, LIV, 4/2008, pp. 379-405.
} 
The strong domestic slave trade also lent it support to strengthening anti-slave trade laws. The relatively healthy environment in eastern slave states like Virginia and Maryland fostered a brisk trade in slaves with less developed Western territories. These eastern states leveraged their strong representation in the federal government to protect slavery and the domestic slave trade while supporting laws that prohibited foreign slave imports. They were eager to reap the profits of an internal slave trade and supported the abolition of the African slave trade, which competed with their supply of slaves. Until the Civil War, the areas most notorious for breaking anti-slave trade laws by importing slaves were in newer U.S. territories such as Louisiana and Florida where large plantation societies had not been established in the previous century.

In analyzing the Amelia Island's effect on federal slave trade laws, it is important to make the distinction between the slave trade to the United States and the participation in the foreign slave trade by Americans. As these pages will show, the U.S. was much more willing to regulate the slave trade coming toward their territories because it concerned the federal government's authority to regulate commerce.

In 1807, both the United States and Great Britain passed laws to abolish the slave trade. Many leaders from both countries congratulated each other on this accomplishment, exclaiming that ending the slave trade would soon end slavery altogether. While this may have been true for British territories, slavery had become so entrenched in the Americas that this would not be the case, nor would suppression be a simple task. The years spent fearing slave insurrections, and a general belief in the inferiority of people of African descent, made Americans wary of allowing captured slaves to be freed on U.S. soil3. Most Southerners, and many Northerners, argued that if slaves were returned to Africa and shipped back to Africa at great federal expense, they would most likely be re-enslaved anyway. Additionally, with some exceptions, most Americans believed that slaves would be better off living enslaved in the United States than re-enslaved or killed in Africa ${ }^{4}$. Although the act eventually passed, it «came very near being a dead letter»5.

3 DU BOIS, William E.B, The Suppression of the African Slave Trade, New York, Schoken Books, 1969, p. 95.

4 Ibidem, p. 102.

5 Ibidem, p. 110; for more on the slave trade debates see MASON, Matthew, «Slavery Overshadowed: Congress Debates Prohibiting the Atlantic Slave Trade to the United States, 1806-1807», in Journal of Early Republic, 20, 1/2000, pp. 59-81; also ROBINSON, Donald, Slavery in the Structure of American Politics, New York, Harcourt Brace Jovanovich Inc, 1971, pp. 329-332; FEHRENBACHER, Don, op. cit., pp. 144-147. 
The Act to Prohibit the Importation of Slaves passed in March of 1807 and went into effect on January $1,1808^{6}$. There had been considerable compromise in Congress regarding the fate of the Africans as well as the penalty for importing slaves. The act stipulated that no one of African descent could be imported by anyone into the United States with the intent to sell or enslave that person. The intent of the bill was to free illegal slaves or send them to Africa, but in the Constitution, the regulation of slavery was left up to the states, not the federal government. Therefore, in slave states, these captured Africans were often sold to the highest bidder and they were left to endure a life of slavery. While the most important aspect of this slave trade law was its contribution to the expansion of federal powers - no small feat during Jefferson's administration, the law nevertheless illustrates the limits of federal authority ${ }^{7}$. As the Constitution outlined, the federal government could regulate the slave trade, but slavery, and Africans captured on confiscated slave ships, would fall under the jurisdiction of the states.

Even though many people rejoiced in the United States' Act of 1808, the vehicle for enforcing this act was particularly weak ${ }^{8}$. While the law prohibited the slave trade on paper, «there was no especial set of machinery provided for the enforcement of this act»9. With no clear-cut method to regulate traffic, shifting authority, and lack of resources devoted to suppressing the slave trade, the federal government could not effectively end the traffic, even if it had been a priority ${ }^{10}$.

Regarding the significance of the 1808 Slave Trade Act, historian David Eltis argues that while the act set a precedent, there were serious problems in the regulation of the law. In fact, Eltis has found that, from an international perspective, the years 1830 and 1860 had a much more significant impact on the abolition of the slave trade than $1808^{11}$. The Act, while imposing stiff penalties, did not alter the status of Africans in the Americas. The Act treated captured Africans as «merchandise to be transferred from the smuggler to some [other] owner ${ }^{12}$. The prevailing idea that people of African descent could only be a white person's property remained unaltered by this law ${ }^{13}$.

\footnotetext{
${ }^{6}$ See «An Act to Prohibit the Importation of Slaves», ch. 22, 2 Stat. 426 (1807).

7 FINKELMAN, Paul, «The American Suppression of the African Slave Trade», in Akron Law Review, 42, 2009, p. 461; MASON, Matthew, op. cit., pp. 59-72.

8 DU BOIS, William E.B., op.cit., p. 108.

9 Ibidem.

${ }^{10}$ FEHRENBACHER, Don, op. cit., p. 152.

${ }^{11}$ ELTIS, David, «The U.S. Transatlantic Slave Trade», in Civil War History, LIV, 4/2008, p. 722.

${ }_{12}$ FINKELMAN, Paul, op. cit., p. 463.

13 FARROW, Anne, LANG, Joel, FRANK, Jenifer, Complicity, How the North Promoted, Prolonged and Profited from Slavery, New York, Ballantine Books, 2005, p. 155.
} 
From a Constitutional perspective, although the U.S. government was able to prohibit the slave trade after 1808 , it was not granted the power to outlaw slavery, which would have eliminated the demand that kept the slave trade active. Lawmakers were already divided on the issue of slavery, and unwilling to push the law further. When war broke out with Britain in 1812, regulating the slave trade took a back seat over more pressing security measures ${ }^{14}$. At the same time, American privateers took advantage of wartime prizes, capturing British merchant ships, including those carrying slaves. When peace returned, many privateers remained, registering themselves as South American ships and preying on Spanish merchants, capturing thousands of slaves in the process, and selling them in or near American ports, while custom agents initially turned a blind eye.

If Americans could not agree over slavery, most could support government measures taken to control those participating in the black market. Poorly patrolled and frequently changing claims of ownership between the Spanish, French, British and Americans, the southern coastlines were prime targets for privateers seeking to sell their prizes. The subsequent government measures taken during this period against smugglers and "patriot invaders" claiming independence from the Spanish empire did at lease expose the problems in suppressing the slave trade. Increased attention on illegal smuggling operations led to the stricter slave trade laws of 1819 and 1820.

A discussion of slave smuggling would not be complete without mentioning the privateers and pirates that lurked in the Gulf and Caribbean waters because these freebooters participated in the illegal slave trade to the United States, and because the U.S. federal government saw them as a direct threat to national security and legal American commerce. When peace returned after 1815, many privateers were reticent to give up their lucrative trade and registered themselves as South American ships to prey on Spanish merchants. These privateers captured thousands of slaves in the process and sold them in or near American ports, as custom agents turned a blind eye. The Spanish-American governments that commissioned these privateers benefitted through sharing the profits and by crippling enemy trade. Often, however, legal prizes bled into illegal pirating if the legitimacy of the government supporting the privateers was questioned or if the privateers began seizing neutral merchant ships. The Gulf of Mexico and the Caribbean were notorious breeding grounds for these patriot-pirates. The Slave Trade Act of 1808 merely «added one more incentive for smuggling» ${ }^{15}$ by

14 HICKEY, Donald, «American Trade Restrictions during the War of 1812», in Journal of American History, 68, 3/1981, pp. 517-538.

15 DAVIS, William C., The Pirates Lafitte, Orlando, Harcourt Press, 2005, p. 40. 
making desirable African slaves an illegal commodity. The U.S. government mostly ignored these privateers and smuggling operations until these ships began to interfere with U.S. trade. In 1818, the United States asserted its national power to protect its commercial interests by invading Spanish Florida. This action led directly to a near war with Spain, a clearer definition of piracy, and a stronger effort to suppress the slave trade to the United States ${ }^{16}$.

One freebooter in particular made headlines in 1817 and compelled the U.S. government to put a stop to his exploits along the southern U.S. border. Commodore Luis-Michel Aury ran the most widespread smuggling operations in the Gulf of Mexico, Caribbean, and Florida. A handsome, young adventurer, Aury crossed and re-crossed national boundaries and identity. He walked the fine line between a sanctioned patriot and lawless pirate. Born in France in 1788, as a young adult the Revolutionary spirit of the age captured him and Aury joined Mexico in the South American Wars of Independence. His misdeeds in the Gulf of Mexico and Florida, directly contributed to the ratification of the Supplementary Slave Trade Acts of 1818-1820. A sometimespirate, sometimes-patriot of South American independence, his fleet's threats to U.S. commerce, and direct provocation of the U.S. Navy, led to U.S. intervention, and, in this way, linked the slave trade to piracy ${ }^{17}$. As a self-appointed governor of the new republic of Galveston, Aury commissioned privateers to raid Spanish ships in an attempt to weaken the already foundering empire, and wreak havoc on commercial activities in the Gulf ${ }^{18}$. Through his efforts, Galveston became a supply line for the importation of slaves into Louisiana.

His operations did not go unnoticed. In 1817, a newly appointed customs agent in New Orleans took on the vast networks of corruption. The agent, named Beverly Chew, did not like what he saw. He wrote that he was unable to stop the «shameful violations of the slave act, as well as our revenue laws, [...] by a motley mixture of freebooters and smugglers, at Galveston, under the Mexican flag» where many of Aury's collaborators

\footnotetext{
16 Again, it is important to separate the slave trade to the United States and the U.S. participation in the foreign trade. The slave trade acts of 1807 and 1818-1820 address the former and, in conjunction with protecting commerce and U.S. borders, was supported by most Americans. The latter was poorly regulated and would increase dramatically during the nineteenth century.

17 Letters documenting Aury's life can be found in Luis Aury Papers, Manuscript Division, Library of Congress, Washington, D.C. and in DABNEY, Lancaster E., «Luis Aury: The First Governor of Texas under the Mexican Republic» in Southwestern Historical Quarterly, 42, 2/1938, pp. 108-116.

18 BARKER, Eugene C., "African Slave Trade in Texas», in The Quarterly of the Texas State Historical Association, 6, 2/1902, p. 146.
} 
were U.S. citizens ${ }^{19}$. But Beverly Chew was also a businessman. As a customs agent he benefitted from the fees collected at customs, and he also participated in his own smuggling operations. He was not above turning a blind eye to slave importations, when he could profitio.

Although Aury did have a commission in the South American patriot armies and although the United States tacitly condoned the South American revolutions, the violation of U.S. law, no matter how poorly enforced, caused Aury to be regarded by the U.S. government as an illegal pirate rather than a patriotic revolutionary. Smuggled goods could not be regulated and monitored by the federal government and, in the wake of real national security threats generated by the war of 1812, violators could not be tolerated. If Aury had maintained his trade outside of U.S. territory, or solely preyed on Spanish ships, his movements likely would not have been considered threatening to the U.S. The fact that Aury's smuggled slaves may have been considered dangerous by many Americans, made Aury's activities monitored more closely by Chew and his agents $^{21}$.

Not only did Aury smuggled dangerous slaves into the U.S., he also seemed to have no regard for neutrality laws. If Aury had preyed solely on Spanish ships, he perhaps could have maintained his reputation as a patriot, yet it was his fleet's threat to U.S. shipping that raised suspicion. Attacks on the private property of U.S. citizens mounted, presumably under Aury's command. Beverly Chew submitted to Congress letters of protest from American merchants who had been attacked by Aury's corsairs. Their accounts depict Aury's band as ruthless criminals who had no regard for personal belongings or laws of nations. Merchants requested convoy protection from these pirates, as the British Navy had done in the Caribbean, but the United States did not have the naval power to comply. Unable to protect U.S. merchants at sea, Chew could not stop the smuggling of goods into Louisiana ${ }^{22}$.

Customs agent Chew was fighting a losing battle. The United States had only a small squadron patrolling thousands of miles of coastline, but its ships were also at a disadvantage because they could not maneuver into the shallow inlets like the smaller smuggling ships could. In a letter to the Secretary of the Treasury, Chew wrote of the

19 Beverly Chew, quoted in BARKER, Eugene C., op. cit., p. 146; see also OBADELE-STARKS, Ernest, Freebooters and Smugglers, Fayetteville, University of Arkansas Press, 2007.

${ }^{20}$ See OBADELE-STARKS, Ernest, op. cit., pp. 42-45.

${ }^{21}$ Chew to Crawford, August 30, 1817 in Message from the President ... Communicating Information ...of Amelia Island and Galvezton, Dec 15, 1817, Washington, E. De Krafft, 1817, p. 13.

${ }^{22}$ Chew to Crawford, in ibidem, pp. 13, 16-17; for an account of attacks on ships Pomona, Freelove and Firebrand, all U.S. vessels; also of brig Charles see ibidem, p. 25; and Aury's authorization of attacks see ibidem, p. 30. See OBADELE-STARKS, Ernest, op. cit., p. 44. 
«necessity of either granting a certain number of revenue cutters, [...] or that the naval force on this station be enjoined strictly to prevent these privateers from hovering in our waters and violating our laws» ${ }^{23}$. Chew seems to have been frustrated with the smugglers' abilities to thwart his customs agents, and this frustration motivated him to improve the effectiveness of the U.S. government. While he ordered that all ships arriving from the "patriot" town of Galveston be searched, it was not because they were importing goods into New Orleans, but because he suspected that they were not authorized by the Mexican government ${ }^{24}$. Public backlash against the increased government regulations of privateers in New Orleans compelled Chew to justify his actions for capturing privateers in August 1817 after he was accused of «being an enemy to personal liberty» ${ }^{25}$. Chew also complained about the role of United States citizens in these piratical exploits.

Because Spain's slave trade was still legal, its slave ships were targeted by South American privateers and pirates since their human cargo could be worth a king's ransom. In New Orleans, it did not escape Beverly Chew's notice that slaves were being smuggled into the region and purchased by the area planters. But simply knowing about clandestine slave importations did not mean these smugglers could be caught. The U.S.S. Boxer, patrolling off the coast of New Orleans, seized slaves that had been purchased by American planters, but captures appeared more by accident than because of the Navy's effectiveness. Due to inaccurate maps, or perhaps an unwillingness to pursue these smugglers, the commander of the Boxer, John Porter, wrote it «will not be in my power to approach nearer the shore than within ten miles off the Sabine, and not nearer than thirty off the Atchafalya [River] $\gg^{26}$. The waters proved to be dangerous, and the Boxer was lost in October 1817, leaving the coast virtually unpatrolled.

Even if slave ships were captured, there were other obstacles in the way. While the 1808 Act did outline proper legal procedure for the prosecution of slave traders, Chew wrote, "owing to the unfortunate absence of the judge, no decision can be had thereon ${ }^{27}$. Chew was unraveling a complex web of illicit trading, complete with absent judge. Another method employed the technique of bribing corrupt officials to capture illegal slaves and sell them at public market, where the original importers would purchase them at reduced prices. The slaves thus became legal and could be sold to

${ }_{23}$ Chew to Crawford, Aug 1, 1817, in ibidem, p. 11, and Chew to Crawford, October 17, 1817, in $15^{\text {th }}$ Congress, $1^{\text {st }}$ Session, No. 290, p. 136.

24 Chew to Crawford, August 1, 1817, in ibidem, p. 10.

25 Ibidem.

${ }^{26}$ Porter to Crowninshield, June 28, 1817 , in ibidem, p. 35 .

27 Chew to Crawford, August 1, 1817, in ibidem, p. 10. 
planters without risk of capture. This "laundering" of slaves could only be accomplished in states whose laws stipulated that captured slaves be sold for the benefit of the state, but it did prove to be highly effective. Demand was so high for slaves from Africa that the extra expenses paid in bribes did not deter planters ${ }^{28}$. Slave-owners were all too willing to «render [smugglers] every possible assistance»29. In effect, customs agents did seem to be informed of the movements of smugglers but they consistently seemed to arrive a day late and a dollar short. While at Galveston, Commodore Aury sold over three hundred slaves to local planters and took more with him on his way to Florida in July $1817^{30}$. Other reports of slave gangs came too late for officials to organize a capture. Once the smugglers had avoided being caught while unloading slaves, customs agents had no evidence with which to arrest them. The recently imported Africans disappeared into plain view on the plantations. Once there, there was little agents could do to recover the slaves ${ }^{31}$.

More and more accounts labeling Aury and his followers as ruthless pirates came to the attention of the federal government. One source claimed that Aury was not even legitimately authorized by the Mexican government or any former Spanish colony ${ }^{2}$. When rumors started circulating that patriots under General Miña were to attack Pensacola after resupplying in U.S. ports, the alarm was sounded, even though the United States was slow to act, questioning why Miña would threaten U.S. neutrality. Although this rumor proved false, it was one more strike against the patriot cause, although Aury's abandonment of Matagorda in July raised eyebrows ${ }^{33}$. The U.S. could not afford to turn a blind eye to the operations of organizations that posed even a rumored threat to U.S. territory. By the time Aury and his fleet resurfaced in Eastern Florida in September 1817, the United States was convinced he was nothing but a lawless pirate.

In early September 1817, Luis-Michel Aury moved his operations to tiny Amelia Island, in Spanish-claimed Eastern Florida, across the river from St Marys, Georgia. The federal government, although having known for at least a decade that Amelia Island was known for illicit smuggling, had largely ignored the illegal activities. The Amelia Island crisis of the fall of 1817 reveals how closely linked the slave trade was to other commercial interests, and how the effectiveness of U.S. suppression depended on

${ }^{28}$ DAVIS, William C., op. cit., p. 63.

29 Morris to Crowninshield, June 10, 1817, in ibidem, p. 35.

30 Porter to Crowninshield, June 28, 1817, in ibidem, p. 35.

${ }^{31}$ Chew to Crawford, October 17, 1817, in ibidem, p. 14.

$3^{2} 15^{\text {th }}$ Congress, $1^{\text {st }}$ Session, No. 290, "Suppression of Piratical Establishments", Reported on January 10, 1818, p. 137; Chew to Crawford in ibidem, p. 10.

33 Morris to Secretary of Navy, March 14, 1817, in ibidem, p. 22. 
the national and international political climates. As the Spanish empire destabilized and her South American colonies declared independence, the already fuzzy lines between legal and illegal trade in the Americas during the early nineteenth century blurred.

Smuggling at Amelia Island flourished under Aury's command. Several accounts estimated that in two months, nearly one thousand slaves had been smuggled into Georgia from Florida, and a half million dollars' worth of goods had been sold34. Aury's strength, organization, and notoriety led U.S. officials to question his motives 35 . His proximity to the U.S. border was threatening and endangered Monroe's plans for the annexation of Florida for which the U.S. had been in negotiations with Spain. The United States government could no longer overlook this blatant disregard for the law.

Once the U.S.S. Saranac arrived at St. Mary's, Captain John Elton began patrolling American waters for suspicious activity. On October 10, 1817, Elton wrote to the Secretary of the Navy about the capture of two schooners. One ship had illegally captured a British ship, showing that these privateers were willing to prey on any merchant vessel, and the other, the Hornet, had captured two prizes before the crew mutinied. Both of the attacked vessels were owned by American citizens ${ }^{36}$.

Not only did Elton discover that American citizens were fitting out vessels to prey on neutral ships, he soon realized he lacked the authority to put a stop to the illegal operations. Aury was not an American citizen, although many of his followers were, and Aury claimed the island for Mexico, yet Elton was fairly certain Aury had not been officially authorized to do so. «Until I get directions on how to consider the island of Amelia, and the people bound to that place», Elton complained, «it will be impossible to prevent either slaves or goods being smuggled»37. Because the island was considered foreign territory and his brig could not negotiate the smaller inlets where slaves were smuggled, Elton could only search privateers at sea - a task that proved difficult with only one ship.

Slave smugglers also took advantage of the loopholes in customs collecting. Because boats under five tons did not need to have clearance papers, smugglers utilized small boats to transport slaves and prize goods into Georgia ${ }^{3}$. Once they were across the border, it was impossible for government officials to track down the smuggled slaves.

34 LOWE, Richard G., «American Seizure of Amelia Island», in Florida Historical Quarterly, 45, 1/1966, pp. 18-30, see p. 22.

35 Elton to Crowninshield, September 26, 1817, in Message from the President...Communicating Information of the Troops, January 13, 1818, Washington, E. De Krafft, 1818, p. 36.

${ }^{36}$ Elton to Crowninshield, October 10, 1817, in ibidem, p. 16.

37 Elton to Crowninshield, October 10, 1817, in ibidem, p. 28.

${ }^{38}$ Elton to Crowninshield, November 15, 1817, in ibidem, p. 38. 
Despite Elton's best efforts, additional slaves were brought into Fernandina, Florida, and, ostensibly, into Georgia.

Elton found the border region between Florida and Georgia particularly difficult to control. The vague orders from the Secretary of Navy compounded the problem and Elton was often unsure how to carry out his duties. On November $9^{\text {th }}$, tensions escalated between the U.S. Navy and Aury's command. Elton's orders were to «prohibit all vessels freighted with slaves from entering the river St. Mary's»39, but Elton soon found that even this became impossible. The brazen privateers showed no qualms about firing upon U.S. ships. Without firm orders about how to proceed with this turn of events, Elton was once again forced to act as he saw fit.

The Spanish slave ship Tentativa, captured by the Mexican privateer Brutus, sailed into the Fernandina harbor on November 9, 1817. Demanding that the ship be examined by U.S. Navy boats, one of Elton's officers tried to board the ship. The ship fired upon the American cutter who returned fire, but was unable to stop the Tentativa from reaching the safety of Fernandina harbor. Elton then sent a message to Aury, demanding that the ship be surrendered to the United States.

If Aury's authority was recognized, the Tentativa was technically a legitimate prize, and, unless it could be proved that the ship was owned or sailed by Americans, the Navy could not legally claim her. Aury argued that the U.S. had fired upon his ship in Amelia Island waters, while Elton's officer claimed that the scuffle began in neutral waters. Elton clearly had very little respect for Aury's power as a representative of Mexico, writing «I have never been instructed [...] but I really think they hold the island by too precarious a tenor, to be yet so very tenacious of their rights $4^{\circ}$. When Aury did send over the Tentativa, its slaves had been removed and «she appeared in a very filthy state» ${ }^{41}$. The incident did not prevent Aury from commissioning more privateers from Amelia Island. The Tentativa crisis was the last straw for the Navy. The Secretary of the Navy ordered that Amelia Island be taken. This was accomplished in December without a shot being fired.

Although Aury did not contest the U.S. occupation of Amelia Island, his letter to the Navy commander expressed surprise by U.S. action. Aury's "surprise" at the U.S. invasion was grounded in his belief that the United States had no authority to control territory outside its jurisdiction, and that the federal government would not willingly antagonize Spain. Still protesting U.S. action, Aury allowed the troops to enter

39 Graham to Crowninshield, July 17, 1817, in ibidem, p. 11.

$4^{\circ}$ Elton to Crowninshield, November 15, 1817, in ibidem, p. 38.

${ }^{41}$ Ibidem; see also LOWE, Richard G., op. cit., p. 22. 
Fernandina, but didn't evacuate the island for over a month. The repercussions from Aury's invasion had not ceased. Reports of illegal slave trafficking continued after the U.S. seizure of Amelia Island and its increased surveillance in the Gulf. By April, naval ships sent to Florida finally sailed to the Gulf with the orders to patrol a territory so vast that even the addition of four ships had little effect on the rampant smuggling ${ }^{42}$. Customs agents not only lacked the power to enforce U.S. laws but, as in the case of the customs agents in New Iberia, Louisiana, the agent and his men had not received pay for several months. Even after the passing of more stringent slave trade and commercial laws, the government's ability to capture illegal slave traders did not improve significantly.

Perhaps the most compelling evidence explaining why U.S. leaders suddenly were willing to involve resources into stopping the slave trade into American territory comes from accounts referring to the importation of slaves from the West Indies. Convinced these slaves were more violent and willing to foment insurrections, as it has been mentioned, many states enacted anti-slave trade laws in order to prevent slave uprisings43. William McIntosh, a customs collector in Georgia, argued in March 1818 that «African and West India negroes are almost daily illicitly introduced into Georgia»44. It was reported that slave importers were creating a "Botany Bay" of the southern United States, by allowing black criminals to be imported45. Desire for slave labor could not overcome the fear of insurrection.

The destruction of U.S. property and the threat to commerce in 1817 convinced legislators that tougher federal laws needed to be enacted. Legislative acts passed in the three years after the Amelia Island affair reflected Congress's goals to strengthen federal law, particularly as it became clear the extent to which Americans were participating in the illegal smuggling of slaves ${ }^{46}$. This increased attention led to the passing of stricter anti-slave trade laws-the last to be passed until the Civil War.

${ }^{42}$ Chew to Crawford, April 17, 1818, in House... Extracts from Documents in the Departments of State, of the Treasury, and of the Navy, in Relation to the Illicit Introduction of slaves, January 19, 1819, Washington, De Krafft, 1819, p. 7.

43 W.E.B. Du Bois was particularly convinced that the Haitian Revolution sparked anti-slave trade legislation.

44 DU BOIS, William E. B., op. cit., p.114. McIntosh was a Creek chief from Scots-Irish and Creek heritage. He is believed to have used his influential status to circumvent U.S. importation laws. He had led a group of "Friendly Creeks" to assist General Andrew Jackson in the taking of Fort Gadsden (Negro Fort) in 1817. See JENNISON, Watson, Cultivating Race, Lexington, University Press of Kentucky, 2012, pp. 179-180.

45 DU BOIS, William E. B., op. cit.; also Henley in Letter from Secretary of Navy...relating information... slaves into the United States, Jan 7, 1820, Washington, Gales \& Seaton, 1820, p. 5, concerning British ship Neptune.

${ }_{46} \mathrm{Du}$ Bois quotes extensively the remarks of legislators, judges, and other officials who were concerned about the number of slaves imported and the participation of Americans in the trade: 
The Amelia Island affair revealed to the U.S government how powerless it was to control smuggling and piratical operations along its Southern borders. Most of the government's impotence spawned from its inability to legally arrest South American affiliated freebooters. It was clear that the U.S. needed to strengthen its anti-piracy laws. If these laws were to include additional slave trade laws, they reasoned, the federal government could control more commercial activities and justify a stronger border patrol. After 1818, the federal government did try to improve the effectiveness of the suppression of the slave trade to the United States, as a direct result of what they saw as a threat to the security of U.S. commerce. Between 1818 and 1820, three new regulations were enacted to support the Act of 1808 and, as Congress deliberated on how best to improve the non-importation act, information was collected to determine the effectiveness of the 1808 law. Reports from the Secretaries of the Navy and the Treasury left much to be desired.

Because there was no federal record of captured slaves, local customs agents were responsible for their own accounting. This made the inquiry into the actual numbers difficult, and still frustrates many historians. The Secretary of the Treasury, William Crawford, a Georgian and member of the American Colonization Society, wrote to the Speaker of the House, reporting that most slaves were sold to benefit the state although he did mention that the slaves were supposed to be turned over to the colonization society in Georgia47. In a letter written to Crawford, Joseph Nourse, from the Register's Office, claimed that according to the records kept in the office, not one ship had been condemned under the Act of 180848 .

In 1818, Congress reduced the maximum fines and jail sentences for complicity in the slave trade, however the burden of proof was shifted to the defendant, who had to prove that the slaves were not illegally imported. Additionally, the Slave Trade Act of 1819 «changed the regulation of the trade» 49 by rewarding any informer who brought about the capture of illegally imported slaves. The act also called for the imported slaves to be "re-colonized" in Africa, rather than be sold in the United States. The conflict between state and federal laws, however, led many states to regulate slave captures as they saw fit. Even with these new laws, officials still often remained hesitant to allow the federal government to return valuable slaves to Africa.

see DU BOIS, William E. B., op. cit., pp. 123-125. The David Mitchell case, of a Creek Customs agent smuggling Amelia Island slaves from Florida into U.S. territory is particularly compelling, although Mitchell did not receive any significant punishment.

47 Crawford to House Speaker, January 20, 1819, in Letter from Secretary of the Treasury Transmitting... Ships Engaged in the Slave Trade, Washington, De Krafft, 1819, p. 3.

${ }^{48}$ Nourse to Crawford, January 7, 1819, in ibidem, p. 5.

49 FINKELMAN, Paul, op. cit., p. 464; see also, DU BOIS, William E. B., op. cit., pp. 249-250. 
Of the three Supplemental Slave Trade Acts, the most radical act was the Act of 1820, which declared that participation in the slave trade was equal to an act of piracy. This applied both to U.S. citizens participating in the trade and foreigners aboard U.S.owned ships. The original statute actually aimed to more specifically define piracy-a direct consequence of the Spanish Wars for Independence and the incidents at Galveston and Amelia Island. Because of this law, slavers could now be put to death for their crimes, although no one ever was until the onset of the Civil War. Even though the demand for slaves in the expanding southwest was high, most slave owners believed that the growing interstate slave trade could both meet the demand for slaves and protect them from the importation of so-called "undesirable" slaves from the West Indies. In this way, both the anti-slave trade and pro-slavery factions within the U.S. government supported these stronger anti-slave trade laws, all for the sake of protecting American interests $5^{\circ}$.

These Supplemental Slave Trade Acts increased federal appropriations for naval surveillance in the Gulf of Mexico, creating a protocol to "repatriate" captured slaves and a squadron to patrol American ships off the coast of Africa. Additionally, and most significant for the suppression of the slave trade, the Slave Act stipulated that informers could reap huge rewards for aiding in the capture of illegal slaves. ${ }^{51}$ While the law had great potential to be effective, enforcing the law was difficult, particularly as the slave trade itself moved south of the Equator. After 1820, Brazil received the most number of slaves than any other region. Americans continued to participate in the trade, slipping through loopholes in the law and the many blind spots in the slave patrols.

Events at Amelia Island and Galveston in 1817 do show an effort on the federal government's part to crack down on slave importations as an extension of the federal government's protection of legal commerce from freebooters and pirates. Newspaper accounts covering the Amelia Island occupation revealed to the general public how ineffective the Act of 1808 actually was and how complicit American citizens were in the extent of the smuggling from Spanish Florida. The Madison and Monroe administrations knew long before Aury's occupation that Spanish Florida was both a haven for slave smugglers and that the law was ineffective, but there was little they were willing or able to do. Because few Americans at this time supported the slave trade into the United States, primarily because they feared the influx of West Indian slaves and already had a ready supply of American-born slaves, the federal government was

5o This coincided with John Quincy Adams's policy of rejecting British demands to allow for the mutual right of search of all British or American vessels.

${ }^{51}$ FINKELMAN, Paul, op. cit., p. 467. 
able to enact legislation to control the slave trade into the United States. Only when slave smuggling became tangled up in violations of U.S. revenue laws and increased attacks against U.S. merchant ships, did the federal government move towards better suppression of the slave trade.

The Amelia Island incident revealed the holes in many federal laws, not just concerning the slave trade, but also concerning diplomacy with other nations. Although the U.S. tried to justify its invasion of Spanish Florida on Spain's inability to govern the area, relations between Spain and the United States remained strained. Andrew Jackson's invasion of Western Florida in early 1818 only escalated the tensions. It would take another year before Spain finally agreed to cede Florida to the United States, and other two years after that before the U.S. took full possession of it. The United States Navy did prove to be effective at reducing the number of pirate attacks in the Gulf, thus protecting U.S. commerce and preventing slave importations into the U.S., but its efforts stopped short of suppressing American participation in the slave trade. While demand for slaves continued, the illicit slave trade continued to strengthen. With its borders protected, the U.S. would allocate very little government funding to the suppression of the foreign slave trade. It would take another forty years after the passage of the Supplementary Slave Trade Acts for the United States to devote any serious attention to the role of American citizens in the illegal trade. Until then, the foreign trade, especially to Brazil and Cuba, would increase dramatically, often to the financial benefit of American citizens. 


\section{* The author}

Sarah Batterson is a Ph.D. candidate at the University of New Hampshire. Her research analyzes the role of the United States in the suppression of the Atlantic slave trade and the obstacles preventing the effective prohibition of the trade.

URL: < http://www.studistorici.com/progett/autori/\#Batterson >

\section{Per citare questo articolo:}

BATTERSON, Sarah, "A Horde of Foreign Freebooters: The U.S. and the Suppression of the Slave Trade», Diacronie. Studi di Storia Contemporanea: Contrabbandieri, pirati e frontiere: per una storia delle pratiche informali nell'America Centrale (XVII-XXI secolo), 29/04/2013,

URL:< http://www.studistorici.com/2013/04/29/batterson_numero_13/ >

Diacronie Studi di Storia Contemporanea $\beta$ www.diacronie.it

Risorsa digitale indipendente a carattere storiografico. Uscita trimestrale.

redazione.diacronie@hotmail.it

Comitato di redazione: Marco Abram - Jacopo Bassi - Luca Bufarale - Alessandro Cattunar - Elisa Grandi - Deborah Paci - Fausto Pietrancosta - Matteo Tomasoni - Luca Zuccolo

Diritti: gli articoli di Diacronie. Studi di Storia Contemporanea sono pubblicati sotto licenza Creative Commons 2.5 . Possono essere riprodotti a patto di non modificarne i contenuti e di non usarli per fini commerciali. La citazione di estratti è comunque sempre autorizzata, nei limiti previsti dalla legge. 